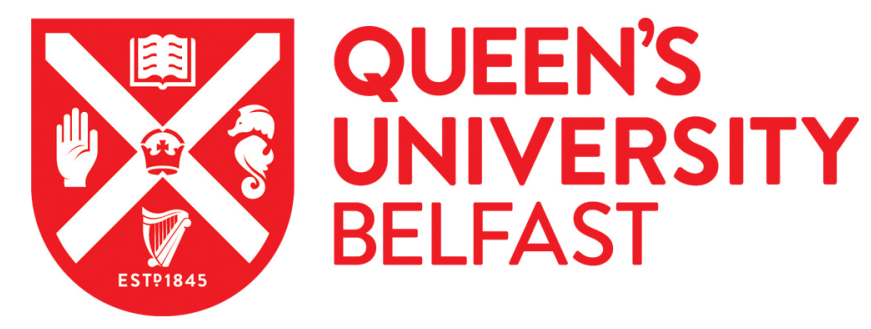

\title{
Mice lacking alpha-tocopherol transfer protein gene have severe alpha-tocopherol deficiency in multiple regions of the central nervous
} system

\author{
Gohil, K., Oommen, S., Quach, H. T., Vasu, V. T., Aung, H. H., Schock, B., Cross, C. E., \& Vatassery, B. T.
} (2008). Mice lacking alpha-tocopherol transfer protein gene have severe alpha-tocopherol deficiency in multiple regions of the central nervous system. Brain Research, 1201, 167-176.

https://doi.org/10.1016/j.brainres.2008.01.044

\section{Published in:}

Brain Research

Queen's University Belfast - Research Portal:

Link to publication record in Queen's University Belfast Research Portal

\section{General rights}

Copyright for the publications made accessible via the Queen's University Belfast Research Portal is retained by the author(s) and / or other copyright owners and it is a condition of accessing these publications that users recognise and abide by the legal requirements associated with these rights.

Take down policy

The Research Portal is Queen's institutional repository that provides access to Queen's research output. Every effort has been made to ensure that content in the Research Portal does not infringe any person's rights, or applicable UK laws. If you discover content in the

Research Portal that you believe breaches copyright or violates any law, please contact openaccess@qub.ac.uk. 


\title{
Mice lacking $\alpha$-tocopherol transfer protein gene have severe $\alpha$ - tocopherol deficiency in multiple regions of the central nervous system
}

\author{
Kishorchandra Gohil ${ }^{1},{ }^{*}$, Saji Oommen ${ }^{1}$, Hung T. Quach ${ }^{3}$, Vihas T. Vasu ${ }^{1}$, Hnin Hnin Aung ${ }^{1}$, \\ Bettina Schock ${ }^{2}$, Carroll E. Cross ${ }^{1}$, and Govind T. Vatassery ${ }^{3,4}$ \\ ${ }^{1}$ Department of Internal Medicine, Genome and Biomedical Sciences Facility University of \\ California, Davis, CA 95616 \\ ${ }^{2}$ Respiratory Research Group, Department of Medicine, Institute of Clinical Science, The Queen's \\ University of Belfast, Belfast, BT12 6BJ, UK \\ ${ }^{3}$ Research Service, V.A. Medical Center, Minneapolis, Minnesota 55417 \\ ${ }^{4}$ Department of Psychiatry And the Graduate Program in Neuroscience, University of Minnesota, \\ Minneapolis, Minnesota 55455
}

\begin{abstract}
Ataxia with vitamin $\mathrm{E}$ deficiency is caused by mutations in $\alpha$-tocopherol transfer protein $(\alpha$-TTP) gene and it can be experimentally generated in mice by $\alpha$-TTP gene inactivation ( $\alpha$-TTP-KO). This study compared $\alpha$-tocopherol $(\alpha-\mathrm{T})$ concentrations of five brain regions and of four peripheral organs from 5 months old, male and female, wild-type (WT) and $\alpha$-TTP-KO mice. All brain regions of female WT mice contained significantly higher $\alpha-T$ than those from WT males. $\alpha$-T concentration in the cerebellum was significantly lower than that in other brain regions of WT mice. These sex and regional differences in brain $\alpha$-T concentrations do not appear to be determined by $\alpha$-TTP expression which was undetectable in all brain regions. All the brain regions of $\alpha$-TTP-KO mice were severely depleted in $\alpha$-T. The concentration of another endogenous antioxidant, total glutathione, was unaffected by gender but was decreased slightly but significantly in most brain regions of $\alpha$-TTPKO mice. The results show that both gender and the hepatic $\alpha$-TTP, but not brain $\alpha$-TTP gene expression are important in determining $\alpha$-T concentrations within the brain. Interestingly, functional abnormality (ataxia) develops only very late in $\alpha$-TTP-KO mice in spite of the severe $\alpha$-tocopherol deficiency in brain starting at an early age.
\end{abstract}

\section{Keywords}

ataxia; brain; gender; liver; transgenic mice; tocopherol transfer protein; vitamin $\mathrm{E}$

Corresponding Author: Kishorchandra Gohil, Genome and Biomedical Sciences Facility, Suite 6510, Internal Medicine, University of California, Davis, CA 95616, kgohil@ucdavis.edu, 5307546932 (phone), 5307528632 (FAX).

Publisher's Disclaimer: This is a PDF file of an unedited manuscript that has been accepted for publication. As a service to our customers we are providing this early version of the manuscript. The manuscript will undergo copyediting, typesetting, and review of the resulting proof before it is published in its final citable form. Please note that during the production process errors may be discovered which could affect the content, and all legal disclaimers that apply to the journal pertain. 


\section{Introduction}

Vitamin E family contains eight lipophilic, naturally occurring compounds that include four tocopherols and four tocotrienols designated as alpha-, beta-, gamma-, and delta-. Vitamin E is essential for a healthy central nervous system (Muller et al., 1983; Nelson, 1980).

Histological studies implicated a role for dietary $\alpha$-T in maintaining CNS structure in rats (Carpenter, 1965). Investigations of chronic vitamin $\mathrm{E}$ deficiency produced by feeding rats $\alpha$ T deficient diets suggested that the CNS was more severely affected than the peripheral nervous system (Towfighi, 1981). Experimental data showing a need for $\alpha$-T for CNS myelination emerged from studies in rats fed diets that varied in $\alpha$-T concentrations (Dinesen and Clausen, 1976). Comparative morphometric analysis of cerebellar synapses of young and old rats indicated a role for $\alpha$-T in preserving synaptic morphology (Bertoni-Freddari et al., 1995; Bertoni-Freddari et al., 1984). These early studies in rodents show that dietary vitamin $\mathrm{E}$ is essential for maintaining the integrity of cellular structures in the CNS.

$\alpha-T$ is also required for the health of human CNS. This is vividly demonstrated in Ataxia with Vitamin E Deficiency (AVED) patients who present with neurological symptoms of varying severity (Cavalier et al., 1998; Gotoda et al., 1995; Schuelke et al., 1999; Tamaru et al., 1997). Neurological deficits similar to those of the AVED subjects are also observed in transgenic mice with a deletion of the $\alpha$-TTP gene (Yokota et al., 2001; Yokota et al., 1987). Furthermore, cerebral cortex of $\alpha$-TTP-knockout ( $\alpha$-TTP-KO) mice has been reported to display attenuated electrophysiological activity compared to the activity displayed by WT mice. Genome-wide mRNA expression analysis of the cerebral cortex from young, asymptomatic $\alpha$-TTP-KO mice suggest a role for $\alpha$-T in myelination and synaptic functions in the CNS (Gohil et al., 2004; Gohil et al., 2003). Similar observations were reported in rats fed $\alpha$-T deficient diets (Hyland et al., 2006). The data from these gene profiling studies appear to provide a molecular basis for the histological and morphometric observations documented in earlier investigations. The studies in young $\alpha$-TTP-KO mice indicate that the loss of molecular markers of neuronal function precedes the decline in neurological phenotype, suggesting the possibility of an important role for brain $\alpha$-T during early development and in the prevention of age-related decline in neurological functions. In view of these and numerous other observations there has been a lot of interest in the use of vitamin $\mathrm{E}$ in human disorders. In clinical practice many attempts have been made to use vitamin $\mathrm{E}$ as a therapeutic agent in disorders of the nervous system (Nelson, 1980; Vatassery et al., 1999).

Electro-retinographic measurements have shown attenuated activities in $\alpha$-TTP-KO mice compared with WT mice indicating retinal degeneration which was accelerated by feeding $\alpha$ T deficient diet to $\alpha$-TTP-KO mice (Tanito et al., 2007). Since some AVED patients develop retinal degeneration (Mariotti et al., 2004; Yokota et al., 1996) the $\alpha$-TTP-KO mice may be relevant to exploring the potential of dietary $\alpha-\mathrm{T}$ in the prevention of age-related retinal degeneration. $\alpha$-T deficiency caused by the deletion of $\alpha$-TTP gene also accelerated Alzheimer Disease phenotype in transgenic mice that overexpress human $\mathrm{APP}_{695}$ with a double mutation (Nishida et al., 2006). Collectively, these studies suggest that $\alpha$-TTP-KO mice offer an in vivo model for identifying molecular and cellular mechanisms relevant to human CNS pathological changes that occur with aging and that may be ameliorated by dietary antioxidants like $\alpha$-T. The model may also have utility in testing neuroprotective effects of other members of vitamin E family such as tocotrienols (Sen et al., 2007)

An understanding of the role of $\alpha$-TTP in brain would be aided by relating $\alpha$-T levels in the $\alpha$-TTP-KO mice with biochemical parameters. Yokota et.al (Yokota et al., 2001) have shown that $\alpha$-T is very low in two brain regions and that the levels reached quantifiable levels only after feeding a diet high in vitamin E. To characterize the role of $\alpha$-TTP gene in the retention, distribution and biological actions of $\alpha-\mathrm{T}$ in the CNS, we have determined $\alpha$-T, cholesterol, 
total glutathione and the expression of $\alpha$-TTP gene from several brain regions. We have also examined whether gender influences brain concentrations of the three compounds.

\section{Results}

Whole body weights of female mice were significantly ( $p<0.0001$ ) lower (by $~ 28 \%$ ) than those of the male mice. However, absence of $\alpha$-TTP gene did not affect whole body weights.

\section{Concentrations of $\alpha-T$ in WT male and female brains}

In order to examine the effects of $\alpha$-TTP gene deficiency, sex and dietary $\alpha$-T on the $\alpha$-T concentrations of various brain regions we determined $\alpha-T$ in brain stem, cerebral cortex, cerebellum, hippocampus and mid-brain. Figure 1 shows that the $\alpha$-T concentrations of all five brain regions from female mice were significantly ( $<<0.005$ ) higher (by $\sim 40 \%$ ) than those of the male mice. Furthermore, $\alpha$-T concentrations of cerebellum were significantly $(p<0.001)$ lower (by $\sim 30 \%$ ) than those of the other brain regions.

Cholesterol is a membrane lipid that has several physico-chemical and biological characteristics similar to $\alpha$-T. Therefore, we determined cholesterol in the different brain regions and the results are given in Figure 2. In contrast to $\alpha$-T, cholesterol content did not change with gender.

\section{Expression of $\alpha$-TTP protein and mRNA in tissue homogenates}

Data in Figure 1 showed that cerebellum contained significantly ( $p<0.001)$ lower $(\sim 30 \%) \alpha-T$ concentrations than that in hippocampus and three other brain regions in both, male and female mice. $\alpha$-TTP protein is implicated in the retention of $\alpha$-T in liver (Meier et al., 2003;Traber and Arai, 1999) and prostate cancer cells (Ni et al., 2007). We, therefore, determined the expression of $\alpha$-TTP mRNA and protein in cerebellum, cerebral cortex and liver. Figure 3 shows that $\alpha$-TTP protein expression was below the limit of detection in cerebral cortex and cerebellum of WT mice whereas it was abundantly expressed in livers from WT mice. As expected, $\alpha$-TTP expression was below detection limits in both brain and liver from the $\alpha$-TTPKO mice. Similarly, $\alpha$-TTP mRNA expression, determined by qRT-PCR was undetectable in the two brain regions (Figure 4), supporting the immunoblot data (Figure 3). Collectively these data suggest that $\alpha$-TTP mRNA and its encoded protein are expressed at very low concentrations in the brain and do not appear to determine the region specific differences in $\alpha-T$ concentrations.

\section{Scavenger-receptor B1 (SR-B1) expression in cerebral cortex and cerebellum}

SR-B1 regulates tissue $\alpha$-T concentrations (Mardones et al., 2002). The expression of SR-B1 was assayed by immunoblot analysis (Figure 5). The data show abundant expression of the $\sim 82 \mathrm{kDa}$ receptor in livers and adrenal glands but very low expression in cerebral cortex, cerebellum and medulla. A $\sim 57 \mathrm{kDa}$ product is also seen in livers and adrenal glands and is likely to be unglycosylated SR-B1 as suggested by the antiserum manufacturer (AbCam Data sheets, Cambridge, MA, USA).

\section{$\alpha-T$ concentrations in all five brain regions of $\alpha$-TTP-KO mice are very low and are much lower than the concentrations achieved by dietary vitamin E deficiency}

Data in Figure 6 show $\alpha$-T concentrations in the five brain regions from 5 month-sold male mice. $\alpha$-T concentrations in all the five brain regions were highly significantly $(\mathrm{p}<0.00001)$ lower in the $\alpha$-TTP-KO mice than those in the respective regions of their WT-littermates. $\alpha$-T concentrations in the brains of the $\alpha$-TTP-KO mice were somewhat close to the limit of quantitation of the assay. However, it was measurable. It is important to note that this severe 
depletion of brain $\alpha$-T concentrations occurred in spite of the presence of sufficient $\alpha$-T (35 IU/Kg diet) in the diet of the $\alpha$-TTP-KO mice. Notably, such low $\alpha$-T concentrations could not be achieved in the brains of age and sex matched WT mice by feeding the mice a semi-synthetic diet made from vitamin $E$ stripped oil with no added $\alpha$-T. The five brain regions of female mice showed a very similar pattern of $\alpha$-T concentrations to that of male mice (data not shown). We have also determined cholesterol concentrations in the brains of these mice and the data are given in Figure 7. These data show that the absence of $\alpha$-TTP gene did not alter cholesterol concentrations in the five brain regions.

\section{Decreases in tissue $\alpha-\mathrm{T}$ concentrations in $\alpha$-TTP-KO mice in peripheral tissues vary with the anatomic site}

Figure 8 shows $\alpha$-T concentrations in liver, heart, testes and ovaries from 5 months-old WT and $\alpha$-TTP-KO mice. The tissues from female mice have significantly $(\mathrm{p}<0.03-0.001)$ higher $\alpha$-T than those from the male mice. Furthermore, the absence of $\alpha$-TTP gene significantly (p $<0.0001)$ decreased the $\alpha$-T concentrations of all the tissues. But the magnitude of the decrease $(\sim 90 \%)$ was greater in heart, testes and ovaries compared to that $(\sim 50 \%)$ in the liver suggesting that different regulatory mechanisms may determine $\alpha$-T concentrations in liver.

\section{Severe $\alpha-T$ deficiency in the CNS has small but significant effect on total glutathione}

It has been suggested that vitamin $\mathrm{E}$ has strong biological interactions with other endogenous antioxidants such as vitamin $\mathrm{C}$ and GSH. Therefore, we determined total glutathione (tGSH), a water-soluble endogenous antioxidant, in tissues of five months-old wild type and $\alpha$-TTPKO animals. Figure 9 shows tGSH concentrations in tissues of female mice. Within the five distinct anatomical regions of the brain, cortex contained the highest concentrations of tGSH and brainstem the lowest concentrations. In contrast to $\alpha$-T which showed significantly higher concentrations in female tissues compared to males (Figure 1), tGSH concentrations were not different among males and females (data not shown). The absence of $\alpha$-TTP gene and the resulting $\alpha$-T deficiency resulted in significantly $(P<0.034-0.001)$ lower $(7 \%-18 \%)$ tGSH in most but not all the tissues from both male and female mice (Figure 9).

\section{DISCUSSION}

\section{Occurrence of severe $\alpha-T$ deficiency in all brain regions of $\alpha$-TTP-KO mice in spite of feeding $\alpha-T$ sufficient diet}

In this study we provide comprehensive profiles of $\alpha$-T concentrations in five distinct brain regions of five months-old male and female mice that are deficient in the $\alpha$-TTP gene and, compare them with the wild-type "littermates". Data (Figure 6) show that the brains of $\alpha$-TTP$\mathrm{KO}$ mice are severely deficient in $\alpha-\mathrm{T}$ in spite of feeding a basal, rodent chow containing sufficient concentrations of $\alpha-\mathrm{T}$ (35 IU/Kg diet). It should also be stressed that the concentrations of brain $\alpha$-T in these mice are significantly $(\mathrm{p}<0.001)$ lower than those fed $\alpha$ $\mathrm{T}$ deficient diets (Figure 6). Thus, the $\alpha$-TTP-KO mice offer an advantage over diet-induced $\alpha$-T deficiency because: a), extremely low concentrations of $\alpha$-T in the CNS can be obtained, possibly from birth and $b$ ), they overcome the frequent criticism about vitamin $E$ deficient diets that such diets contain undesirable oxidation products of dietary lipids generated ex-vivo and that these oxidation products may contribute significantly to oxidative stress in vivo.

Previous studies have shown that cerebellum and cortex from $\alpha$-TTP-KO mice have very low or undetectable concentrations of $\alpha-\mathrm{T}$ (Gohil et al., 2004; Gohil et al., 2003; Leonard et al., 2002; Yokota et al., 2001). Unlike previous studies we have determined $\alpha$-T in several brain regions. The current study further shows that all CNS regions (cortex, hippocampus, midbrain, cerebellum and brainstem) examined, from both female and male mice, are severely depleted (>95\% of normal) in $\alpha$-T. Furthermore, in contrast to the previous study which used 15 months- 
old mice (Leonard et al., 2002) this study used younger (5 months old) mice and showed $\alpha-\mathrm{T}$ deficiency that is very severe starting at a much younger age ( 5 months old). Another important observation made here is that in spite of the extremely low $\alpha$-T in the CNS, the young mice do not display ataxia which appears only after 9 months of age (Gohil et al., 2004; Yokota et al., 2001). Thus the development of clinical ataxia in the $\alpha$-TTP-KO animals has a long latency, possibly due to the presence of unknown mechanisms that sustain normal cerebellar functions in young $\alpha$-TTP-KO mice whose brains are almost devoid of $\alpha$-T.

\section{Liver is spared from severe $\alpha$-T deficiency in $\alpha-T T P-K O$ mice}

Livers of $\alpha$-TTP-KO mice underwent less severe depletion of $\alpha$-T than other extra-hepatic tissues which showed large (>80\%) and highly significant (p<0.0001) $\alpha$-T deficiency (Fig. 8). Since chylomicron remnants are the primary source of $\alpha$-T for liver (Bjorneboe et al., 1986;Kaempf-Rotzoll et al., 2003;Traber et al., 1988) and hepatic $\alpha$-T is less severely depleted than that of the other tissues, it is inferred that $\alpha$-TTP deficiency has a modest effect on the uptake of $\alpha$-T from chylomicron remnants.

\section{Tissue $\alpha-T$ concentrations are not directly correlated with $\alpha$-TTP expression}

In agreement with our previous studies using male mice (Vatassery et al., 1984a; Vatassery et al., 1984b; Vatassery et al., 1984c) the current experiments demonstrated that cerebellum from both female and male mice contained significantly $(\mathrm{p}<0.001)$ lower $(\sim 30 \%) \alpha$-T than cortex and other brain regions (Fig.1). If $\alpha$-TTP is essential for the retention of $\alpha$-T (Meier et al., 2003; Spector and Johanson, 2007) then we would predict higher expression of $\alpha$-TTP in the cortex compared to that in the cerebellum. Experimental data do not support this prediction. A previous study (Hosomi et al., 1998) indicated higher expression of $\alpha$-TTP mRNA in the cerebellum compared to that in the cortex suggesting an inverse relationship between $\alpha$-TTP mRNA expression and $\alpha-T$ concentrations. We also note that Yokota et al., 2001 detected very low levels of $\alpha$-TTP in brain regions compared to that in liver (Yokota et al., 2001); however $\alpha-\mathrm{T}$ concentration in the two organs are very similar, further suggesting a lack of causal relationship between $\alpha$-TTP expression and whole tissue $\alpha$-T concentrations. It is also noteworthy that $\alpha$-TTP was not detected in WT-heart (Yokota et al., 2001) but $\alpha$-T concentrations in WT-hearts hearts are similar to those of WT-livers (Fig. 8) which has abundant expression of $\alpha$-TTP. Data from liver and lungs (Gohil et al., 2007) of WT mice also suggest a lack of correlation between $\alpha$-TTP mRNA expression and tissue $\alpha$-T concentrations. $\alpha$-TTP was undetectable by immunoblot analysis of whole homogenates from either the cerebellum or the cortex from either wild type or TTP-KO mice (Fig 3).

Our assays cannot exclude the possibility that in many tissues, including the CNS, the expression of $\alpha$-TTP is specifically localized to a few cells within the tissue. Previous studies have reported such discrete cellular localization of $\alpha$-TTP. For example, the occurrence of $\alpha$ TTP has been reported in rat cerebellar Bergman glia (Hosomi et al., 1998) and in Purkinje cells of AVED patients, in selected cells of patients with oxidative stress related to neurodegeneration (Copp et al., 1999) and in trophoblast, fetal capillaries, endothelium and amnion epithelium of human term placenta (Muller-Schmehl et al., 2004). However, the presence of a few $\alpha$-TTP expressing cells in a tissue may not account for bulk $\alpha$-T determined in whole tissue homogenates.

\section{Proteins other than $\alpha$-TTP that may modify tissue $\alpha$-T concentrations}

A number of genes other than that encoding $\alpha$-TTP are implicated in the uptake, retention and secretion of $\alpha$-T (Kaempf-Rotzoll et al., 2003; Mardones and Rigotti, 2004; Schneider, 2005). These include genes encoding scavenger receptor B-1 (SR-B1) (Goti et al., 2001; Mardones et al., 2002; Reboul et al., 2006), phosphilipid transfer protein (Desrumaux et al., 1999; Desrumaux et al., 2005; Huuskonen et al., 2001; Jiang et al., 2002), apolipoprotein E 
(Reich et al., 2001; Vatassery et al., 2006) lipoprotein lipase (Goti et al., 2002) and tocopherol binding proteins (Kempna et al., 2003; Stocker and Azzi, 2000). In this study we assayed the expression of SR-B1 and found it to undetectable in the three brain regions of WT mice (Fig. 5). SR-B1 was highly expressed in adrenal glands and liver (Fig. 5). Low expression of SRB1 in brain compared to that in liver and adrenal glands has been previously documented (Srivastava, 2003). These data suggest that SR-B1 may not play an important role in the uptake of $\alpha$ - $\mathrm{T}$ in brain.

Effect of gender on $\alpha$-tocopherol concentrations in the brain-Our data (Figure 1) show that $\alpha$-T concentrations in different brain regions in females are higher than those in the corresponding areas of the male brains. This difference was not altered by $\alpha$-TTP deficiency and thus seems to be a more fundamental phenomenon. Literature contains reports of similar differences in $\alpha$-T contents of tissues from males and females. It has been shown that $\alpha-\mathrm{T}$ content of some tissues in female rats is higher than that of males (Chen et al., 1992). Others have confirmed this finding (Lopez-Torres et al., 1998) . Feingold et al.(Feingold et al., 1993) have reported that ovariectomy of rats resulted in decreased concentrations of $\alpha$-T in both adrenals and liver and that this effect can be prevented by administration of estradiol at the time of surgery. These reports and our data indicate a fundamental difference in the handling of $\alpha$-T by male and female brains. Additional investigations are needed to understand the significance and mechanism of this phenomenon.

\section{Conclusions}

Transgenic mice lacking the $\alpha$-TTP gene offer an experimental model of $\alpha$-T deficient AVED patients as well as for the production of severe $\alpha$-T deficiency in brain that is unattainable by dietary manipulation. Our study shows that the differences in tissue $\alpha$-T concentrations cannot be accounted for by the extent of expression of $\alpha$-TTP gene whose expression levels are high in the liver and below the limits of detection in all the brain regions and in some other tissues examined. The present data also show a significant effect of sex on the concentrations of $\alpha-T$ in all brain regions and gonads of WT mice. The absence of $\alpha$-TTP gene dramatically decreases the levels of $\alpha$-T in all regions of the brain and this effect is much more severe than that observed in brains of mice fed vitamin E-deficient diets. It is particularly noteworthy that development of ataxia in the $\alpha$-TTP-KO mice takes place only when the animals are more than 9 months of age in spite of the fact that the depletion of $\alpha$-T occurs much earlier (probably at birth).

\section{Experimental Procedure}

\section{Chemicals}

The chemicals used were of reagent grade purity from standard sources. Solvents for chromatography were HPLC grade from Fisher Scientific, Itasca, ILL, U.S.A. Standard d- $\alpha-$ T was purchased from Kodak Laboratory Chemicals, Rochester, NY, USA. Absolute ethanol was obtained from Aaper Alcohol and Chemical Company, Shelbyville, Kentucky, USA and was redistilled prior to use. Most of the reagent grade chemicals were from Sigma Chemicals, St. Louis, MO, USA.

Diets-were purchased from Purina Test Diets, Richmond, PA, USA. The composition of diets (AIN-93G) used in these experiments followed the recommendation for rodent diets by the American Institute of Nutrition (Reeves et al., 1993). The basal $\alpha$-T deficient diet (-E) was obtained by substituting the source of fats in AIN-93G diet with vitamin E-stripped corn oil and removing $\alpha$-T from the vitamin mix. The diet containing $35 \mathrm{IU}$ of $\alpha-\mathrm{T} / \mathrm{Kg} \operatorname{diet}(\mathrm{E})$ was produced by the addition of the appropriate amounts of dl- $\alpha$-tocopheryl acetate to the $\alpha-\mathrm{T}$ deficient diet. The mice were allowed to feed on the pelleted diets ad libitum. 
Mice-were bred on C57BL6 genetic background and obtained from the in-house colony at UC Davis. All the experiments with mice were approved by UC Davis Animal Use Committee. Heterozygous $\alpha$-TTP female pairs were housed with a heterozygous male. The pregnant mice were separated from the males and were allowed to give birth. The mice were allowed to feed on the basal, $35 \mathrm{IU} \alpha-\mathrm{T} / \mathrm{Kg}$ diet. The pups were weaned for one-month and genotyped using DNA extracted from tail-clippings $(<1 \mathrm{~cm})$. The $\alpha$-TTP-KO mice were then selected for further experiments. One month old wild-type C57Bl6 mice that were used in studies of dietary $\alpha-\mathrm{T}$ deficiency were obtained from Jackson Laboratory (Bar Harbor, Maine, USA) and were allowed to consume vitamin $\mathrm{E}$ deficient diet for 4 months.

\section{Genotyping of mice}

DNA was extracted from clipped tails with Qiagen DNA extraction kit as described by the manufacturer. Aliquots of extracted DNA were subjected to PCR protocol as previously described (Terasawa et al., 2000) .

\section{Tissue dissection, storage and processing}

After weaning, the mice were fed basal or $\alpha$-T deficient diets for 4 months and then euthanized with an overdose of pentobarbital ( $>100 \mathrm{mg} / \mathrm{kg}$ body wt). Tissues were rapidly dissected and frozen on dry-ice followed by storage at $-70^{\circ} \mathrm{C}$ until further analysis.

\section{Biochemical assays}

Determination of $\alpha-T$ and cholesterol-The tissues (brain stem, cerebral cortex, hippocampus, cerebellum, midbrain, hearts, livers, ovaries, and testes) were weighed and homogenized in $0.32 \mathrm{M}$ sucrose, $10 \mathrm{mM}$ HEPES, $1 \mathrm{mM}$ EDTA at $\mathrm{pH} 7.4$ and stored at $-70 \mathrm{C}$.

The $\alpha$-T and cholesterol assays were done within two to four months. Details of the method have been reported (Vatassery et al., 1997; Vatassery et al., 1993). Briefly, $2 \mathrm{ml}$ of ethanol containing $0.025 \%(\mathrm{w} / \mathrm{v})$ butylated hydroxytoluene (BHT) and $0.1 \mathrm{ml}$ of $30 \%(\mathrm{w} / \mathrm{v})$ ascorbic acid were pipetted into tubes containing tissue homogenates. The mixture was saponified at $60^{\circ} \mathrm{C}$ after the addition of $1 \mathrm{ml} \mathrm{10 \%} \mathrm{(w/v)} \mathrm{KOH.} \mathrm{Sample} \mathrm{tubes} \mathrm{were} \mathrm{cooled} \mathrm{and} 2 \mathrm{ml}$ of water was added followed by $2 \mathrm{ml}$ of hexane containing $0.025 \%(\mathrm{w} / \mathrm{v})$ BHT. The tocopherols and cholesterol were extracted into the hexane phase by vortexing the samples. Part of the hexane extract was evaporated down and the residue was redissolved in mobile phase and analyzed by liquid chromatography for tocopherol using the following conditions: column $=$ ultrasphere ODS, 5 microns, $4.6 \times 150 \mathrm{~mm}$ from Beckman Instruments; mobile phase $=5.5 \%$ water in methanol with final $7.5 \mathrm{mM} \mathrm{NaH} \mathrm{PO}_{4}$; flow rate $=2.5 \mathrm{ml} / \mathrm{min}$. $\alpha$-T was detected electrochemically utilizing Coulochem 5100; the detecting electrodes consisted of the 5011 analytical cell (detector 1 at $-0.25 \mathrm{~V}$ and detector 2 at $+0.55 \mathrm{~V}$ ) and 5021 conditioning cell set at $-0.75 \mathrm{~V}$.

One portion of the hexane extract was used for cholesterol determination by a gas chromatographic method reported earlier (Vatassery et al., 1997). After evaporation of the solvent, trimethylsilyl ether derivatives of cholesterol were prepared using bis(trimethyl silyl) trifluoroacetamide and analyzed by a Hewlett Packard (Avondale, PA) model 5880 gas chromatograph equipped with a flame ionization detector and a capillary column (DB1 column, 30 meters $\times 0.324 \mathrm{~mm}$, film thickness $0.25 \mu \mathrm{m}$; temperature programming conditions: oven temperature initial $50^{\circ} \mathrm{C}$, initial time $3 \mathrm{~min}$, program rate $30^{\circ} \mathrm{C}$ per min, final value $290^{\circ} \mathrm{C}$, second program rate $1^{\circ} \mathrm{C}$ per min, final temperature $300^{\circ} \mathrm{C}$ and keep at $300^{\circ} \mathrm{C}$ for $5 \mathrm{~min}$ ). Under these conditions the retention times of the internal standard cholestane and cholesterol were 14.82 and 17.26 minutes, respectively. 
Determination of total glutathione-The method of Ubbink et.al. (Ubbink et al., 1991) as modified by Castagna et.al (Castagna et al., 1995) was used. Briefly, the brain homogenate was incubated on ice with tri-n-butyl phosphine to reduce GSSG and the solution was then mixed with $5.5 \%$ trichloroacetic acid containing $0.55 \mathrm{mM}$ EDTA. Total GSH in the acid extract was derivatized with 7-fluor-2.1.3-benzoxazole-4-sulfonamide (SBDF) and analyzed by reverse phase HPLC with fluorescent detection.

Protein concentrations-were determined by the Lowry technique as modified by arkwell et al (Markwell et al., 1978).

\section{Immunoblot analysis for $\alpha$-TTP and scavenger receptor B1 expression in tissue omogenates}

All materials were from Santa Cruz Biotechnology Inc. (CA) and their catalog numbers are given in parenthesis. The procedures were as described in Western Blotting Protocol, Santa Cruz Biotechnology, Inc.. Briefly, $50 \mathrm{mg}$ frozen tissue was homogenized in ice-cold 200$500 \mu \mathrm{L}$ of lysis buffer (sc-24948) containing complete protease inhibitor cocktail (sc-29130) with freshly added phenylmethylsulfonyl fluoride (sc-3597). The homogenates were centrifuged and protein determined in the supernatants. Aliquots containing $40 \mu \mathrm{g}$ protein were mixed with an equal aliquot of sample buffer (sc-24945), boiled for 3 mins and 10-20 $\mu 1$ were loaded per lane in 4-20\% pre-cast Tris-glycine gels (Invitrogen, Carlsbad, CA).

Electrophoretically resolved proteins were transferred to polyvinylidene fluoride membranes, blocked with Blotto A (sc-2323) and incubated with anti- $\alpha$-TTP rabbit antiserum, (1/5000 dilution in Blotto A) overnight at $4^{\circ} \mathrm{C}$. The $\alpha$-TTP-antiserum was a generous gift from Professor Maret Traber, Oregon State University, OR. Scavenger receptor B1 (SR-B1) antibody was a rabbit antiserum and used at 1/500 dilution as suggested by manufacturer (AbCam, Cambridge, MA). $\alpha$-TTP- antiserum or SR-B1 antibody bound proteins were visualized with goat-antirabbit horseradish peroxidase conjugated antiserum (1/5000 dilution, room tempt, $1 \mathrm{hr}$ ) and Chemiluminescence Luminol Reagent (sc-2048).

\section{Quantitative RT-PCR (qRT-PCR) of $\alpha$-TTP mRNA expression in tissues}

Total RNA was extracted from tissues of female mice as previously described (Gohil et al., 2003). Approximately 50mg of tissue from each female mouse was homogenized in $1 \mathrm{ml}$ of Trizol Reagent (Invitrogen, Carlsbad, CA) and a pellet of total RNA was obtained using the procedures described by the manufacturer. The total RNA pellet from each tissue was dissolved in RNAase-DNAase free water to obtain a concentration of $2.5 \mu \mathrm{g}$ of RNA/ $\mu 1$ of solution.

An aliquot equivalent to $5 \mu \mathrm{g}$ of total RNA extracted from each brain region was reversetranscribed to obtain cDNA in a final volume of $20 \mu \mathrm{L}$ solution consisting of buffer, oligo-dT primer, DTT, dNTPs and Superscript-II reverse transcriptase (Invitrogen, Carlsbad, CA). Realtime polymerase chain reaction (RT-PCR) method with SYBR as fluorescent reporter was used to quantify the expression of $\alpha$-TTP mRNA. The primer sequences were: Glyceraldehyde-3phosphate dehydrogenase GCAACAGGGTGGTGGACCT (forward),

GGATAGGGCCTCTCTTGCTCA (reverse); $\alpha$-TTP:

TCTACAGAGAACACTAATGAGCAATGTG(forward), TGGTGAAGCCATGTGGAAAGT (reverse).

The reaction was carried out in 96 well optical plates containing $6.25 \mathrm{ng}$ cDNA in each well. The applied RNA quantity was normalized by amplifying cDNA samples simultaneously with glyceraldehyde-3-phosphate dehydrogenase (GAPDH) specific primers. The transcript concentrations were measured by real-time RT-PCR using the ABI PRISM 7700 Sequence detection system (PE Applied Biosystems, Foster City, CA). The PCR amplification parameters were: initial denaturation step at $95^{\circ} \mathrm{C}$ for $10 \mathrm{~min}$ followed by 40 cycles, each at $95^{\circ} \mathrm{C}$ for $15 \mathrm{~s} \mathrm{(melting)} \mathrm{and} 60^{\circ} \mathrm{C}$ for $1 \mathrm{~min}$ (annealing and extension). The $2^{-} \Delta \Delta C \mathrm{~T}$ method 
(Livak and Schmittgen, 2001) was used to calculate relative changes in gene expression determined from real-time quantitative PCR experiments (Applied Biosystems User Bulletin No.2 (P/N4303859). The threshold cycle, $C_{t}$, which correlates inversely with the target mRNA concentrations, was measured as the cycle number at which the SYBR Green emission increases above a preset threshold concentration. The specific mRNA transcripts were expressed as fold difference in the expression of the specific mRNAs in RNA samples from the brain regions of the $\alpha$-TTP-KO mice compared to those from the brain regions of WT mice.

\section{Statistical data}

for $\alpha$-T and cholesterol and total GSH concentrations and, for changes in gene expression (foldchange) obtained by qRT-PCR were analyzed by GraphPad PRISM (version 4.0; GraphPad

Software, San Diego, CA). The data are reported as means \pm SEMs. An unpaired Student's $t$ test was used for comparisons between the experimental mouse groups. All data were considered statistically significant when $P$ values were $\leq 0.05$.

\section{References}

Bertoni-Freddari C, Fattoretti P, Caselli U, Paoloni R, Meier-Ruge W. Vitamin E deficiency as a model of precocious brain aging: assessment by X-ray microanalysis and morphometry. Scanning Microsc 1995;9:289-301. discussion 301-282. [PubMed: 8553024]

Bertoni-Freddari C, Giuli C, Pieri C. Effect of chronic vitamin E deficiency on the synapses of cerebellar glomeruli in young rats. Mech Ageing Dev 1984;24:225-232. [PubMed: 6717090]

Bjorneboe A, Bjorneboe GE, Bodd E, Hagen BF, Kveseth N, Drevon CA. Transport and distribution of alpha-tocopherol in lymph, serum and liver cells in rats. Biochim Biophys Acta 1986;889:310-315. [PubMed: 3790578]

Carpenter S. A Histochemical Study of Oxidative Enzymes in the Nervous System of Vitamin E-Deficient Rats. Neurology 1965;15:328-332. [PubMed: 14280595]

Castagna A, Le Grazie C, Accordini A, Giulidori P, Cavalli G, Bottiglieri T, Lazzarin A. Cerebrospinal fluid S-adenosylmethionine (SAMe) and glutathione concentrations in HIV infection: effect of parenteral treatment with SAMe. Neurology 1995;45:1678-1683. [PubMed: 7675226]

Cavalier L, Ouahchi K, Kayden HJ, Di Donato S, Reutenauer L, Mandel JL, Koenig M. Ataxia with isolated vitamin E deficiency: heterogeneity of mutations and phenotypic variability in a large number of families. Am J Hum Genet 1998;62:301-310. [PubMed: 9463307]

Chen HW, Cook LR, Hendrich S. Gender and dietary fat affect alpha-tocopherol status in F344/N rats. Lipids 1992;27:844-846. [PubMed: 1491600]

Copp RP, Wisniewski T, Hentati F, Larnaout A, Ben Hamida M, Kayden HJ. Localization of alphatocopherol transfer protein in the brains of patients with ataxia with vitamin E deficiency and other oxidative stress related neurodegenerative disorders. Brain Res 1999;822:80-87. [PubMed: 10082886]

Desrumaux C, Deckert V, Athias A, Masson D, Lizard G, Palleau V, Gambert P, Lagrost L. Plasma phospholipid transfer protein prevents vascular endothelium dysfunction by delivering alphatocopherol to endothelial cells. Faseb J 1999;13:883-892. [PubMed: 10224231]

Desrumaux C, Risold PY, Schroeder H, Deckert V, Masson D, Athias A, Laplanche H, Le Guern N, Blache D, Jiang XC, Tall AR, Desor D, Lagrost L. Phospholipid transfer protein (PLTP) deficiency reduces brain vitamin E content and increases anxiety in mice. Faseb J 2005;19:296-297. [PubMed: 15576481]

Dinesen B, Clausen J. The influence of vitamin E deficiency and combined deficiency in vitamin E and polyunsaturated fatty acids on the biosynthesis and degradation of rat central nervous system myelin. Nutr Metab 1976;20:95-111. [PubMed: 958656]

Feingold IB, Longhurst PA, Colby HD. Regulation of adrenal and hepatic alpha-tocopherol content by androgens and estrogens. Biochim Biophys Acta 1993;1176:192-196. [PubMed: 8452874]

Gohil K, Godzdanker R, O'Roark E, Schock BC, Kaini RR, Packer L, Cross CE, Traber MG. Alphatocopherol transfer protein deficiency in mice causes multi-organ deregulation of gene networks and behavioral deficits with age. Ann N Y Acad Sci 2004;1031:109-126. [PubMed: 15753139] 
Gohil K, Oommen S, Vasu VT, Aung HH, Cross CE. Tocopherol transfer protein deficiency modifies nuclear receptor transcriptional networks in lungs: modulation by cigarette smoke in vivo. Mol Aspects Med 2007;28:453-480. [PubMed: 17400288]

Gohil K, Schock BC, Chakraborty AA, Terasawa Y, Raber J, Farese RV Jr, Packer L, Cross CE, Traber MG. Gene expression profile of oxidant stress and neurodegeneration in transgenic mice deficient in alpha-tocopherol transfer protein. Free Radic Biol Med 2003;35:1343-1354. [PubMed: 14642382]

Goti D, Balazs Z, Panzenboeck U, Hrzenjak A, Reicher H, Wagner E, Zechner R, Malle E, Sattler W. Effects of lipoprotein lipase on uptake and transcytosis of low density lipoprotein (LDL) and LDLassociated alpha-tocopherol in a porcine in vitro blood-brain barrier model. J Biol Chem 2002;277:28537-28544. [PubMed: 12032155]

Goti D, Hrzenjak A, Levak-Frank S, Frank S, van der Westhuyzen DR, Malle E, Sattler W. Scavenger receptor class $\mathrm{B}$, type $\mathrm{I}$ is expressed in porcine brain capillary endothelial cells and contributes to selective uptake of HDL-associated vitamin E. J Neurochem 2001;76:498-508. [PubMed: 11208913]

Gotoda T, Arita M, Arai H, Inoue K, Yokota T, Fukuo Y, Yazaki Y, Yamada N. Adult-onset spinocerebellar dysfunction caused by a mutation in the gene for the alpha-tocopherol-transfer protein. N Engl J Med 1995;333:1313-1318. [PubMed: 7566022]

Hosomi A, Goto K, Kondo H, Iwatsubo T, Yokota T, Ogawa M, Arita M, Aoki J, Arai H, Inoue K. Localization of alpha-tocopherol transfer protein in rat brain. Neurosci Lett 1998;256:159-162. [PubMed: 9855364]

Huuskonen J, Olkkonen VM, Jauhiainen M, Ehnholm C. The impact of phospholipid transfer protein (PLTP) on HDL metabolism. Atherosclerosis 2001;155:269-281. [PubMed: 11254896]

Hyland S, Muller D, Hayton S, Stoecklin E, Barella L. Cortical gene expression in the vitamin E-deficient rat: possible mechanisms for the electrophysiological abnormalities of visual and neural function. Ann Nutr Metab 2006;50:433-441. [PubMed: 16847396]

Jiang XC, Tall AR, Qin S, Lin M, Schneider M, Lalanne F, Deckert V, Desrumaux C, Athias A, Witztum JL, Lagrost L. Phospholipid transfer protein deficiency protects circulating lipoproteins from oxidation due to the enhanced accumulation of vitamin E. J Biol Chem 2002;277:31850-31856. [PubMed: 12105225]

Kaempf-Rotzoll DE, Traber MG, Arai H. Vitamin E and transfer proteins. Curr Opin Lipidol 2003;14:249-254. [PubMed: 12840655]

Kempna P, Zingg JM, Ricciarelli R, Hierl M, Saxena S, Azzi A. Cloning of novel human SEC14p-like proteins: ligand binding and functional properties. Free Radic Biol Med 2003;34:1458-1472. [PubMed: 12757856]

Leonard SW, Terasawa Y, Farese RV Jr, Traber MG. Incorporation of deuterated RRR- or all-rac-alphatocopherol in plasma and tissues of alpha-tocopherol transfer protein--null mice. Am J Clin Nutr 2002;75:555-560. [PubMed: 11864863]

Livak KJ, Schmittgen TD. Analysis of relative gene expression data using real-time quantitative PCR and the 2(-Delta Delta C(T)) Method. Methods 2001;25:402-408. [PubMed: 11846609]

Lopez-Torres M, Thiele JJ, Shindo Y, Han D, Packer L. Topical application of alpha-tocopherol modulates the antioxidant network and diminishes ultraviolet-induced oxidative damage in murine skin. Br J Dermatol 1998;138:207-215. [PubMed: 9602862]

Mardones P, Rigotti A. Cellular mechanisms of vitamin E uptake: relevance in alpha-tocopherol metabolism and potential implications for disease. J Nutr Biochem 2004;15:252-260. [PubMed: 15135148]

Mardones P, Strobel P, Miranda S, Leighton F, Quinones V, Amigo L, Rozowski J, Krieger M, Rigotti A. Alpha-tocopherol metabolism is abnormal in scavenger receptor class B type I (SR-BI)-deficient mice. J Nutr 2002;132:443-449. [PubMed: 11880569]

Mariotti C, Gellera C, Rimoldi M, Mineri R, Uziel G, Zorzi G, Pareyson D, Piccolo G, Gambi D, Piacentini S, Squitieri F, Capra R, Castellotti B, Di Donato S. Ataxia with isolated vitamin E deficiency: neurological phenotype, clinical follow-up and novel mutations in TTPA gene in Italian families. Neurol Sci 2004;25:130-137. [PubMed: 15300460]

Markwell MA, Haas SM, Bieber LL, Tolbert NE. A modification of the Lowry procedure to simplify protein determination in membrane and lipoprotein samples. Anal Biochem 1978;87:206-210. [PubMed: 98070] 
Meier R, Tomizaki T, Schulze-Briese C, Baumann U, Stocker A. The molecular basis of vitamin E retention: structure of human alpha-tocopherol transfer protein. J Mol Biol 2003;331:725-734. [PubMed: 12899840]

Muller-Schmehl K, Beninde J, Finckh B, Florian S, Dudenhausen JW, Brigelius-Flohe R, Schuelke M. Localization of alpha-tocopherol transfer protein in trophoblast, fetal capillaries' endothelium and amnion epithelium of human term placenta. Free Radic Res 2004;38:413-420. [PubMed: 15190938]

Muller DP, Lloyd JK, Wolff OH. Vitamin E and neurological function. Lancet 1983;1:225-228. [PubMed: 6130255]

Nelson. Pathology of Viatmin E deficiency. In: Machlin, LJ., editor. Vitamin E. New York: Marcel Dekker; 1980.

Ni J, Pang ST, Yeh S. Differential retention of alpha-vitamin E is correlated with its transporter gene expression and growth inhibition efficacy in prostate cancer cells. Prostate 2007;67:463-471. [PubMed: 17252538]

Nishida Y, Yokota T, Takahashi T, Uchihara T, Jishage K, Mizusawa H. Deletion of vitamin E enhances phenotype of Alzheimer disease model mouse. Biochem Biophys Res Commun 2006;350:530-536. [PubMed: 17026966]

Reboul E, Klein A, Bietrix F, Gleize B, Malezet-Desmoulins C, Schneider M, Margotat A, Lagrost L, Collet X, Borel P. Scavenger receptor class B type I (SR-BI) is involved in vitamin E transport across the enterocyte. J Biol Chem 2006;281:4739-4745. [PubMed: 16380385]

Reeves PG, Rossow KL, Lindlauf J. Development and testing of the AIN-93 purified diets for rodents: results on growth, kidney calcification and bone mineralization in rats and mice. J Nutr 1993;123:1923-1931. [PubMed: 8229309]

Reich EE, Montine KS, Gross MD, Roberts LJ 2nd, Swift LL, Morrow JD, Montine TJ. Interactions between apolipoprotein $\mathrm{E}$ gene and dietary alpha-tocopherol influence cerebral oxidative damage in aged mice. J Neurosci 2001;21:5993-5999. [PubMed: 11487622]

Schneider C. Chemistry and biology of vitamin E. Mol Nutr Food Res 2005;49:7-30. [PubMed: 15580660]

Schuelke M, Mayatepek E, Inter M, Becker M, Pfeiffer E, Speer A, Hubner C, Finckh B. Treatment of ataxia in isolated vitamin E deficiency caused by alpha-tocopherol transfer protein deficiency. $\mathrm{J}$ Pediatr 1999;134:240-244. [PubMed: 9931538]

Sen CK, Khanna S, Roy S. Tocotrienols in health and disease: the other half of the natural vitamin E family. Mol Aspects Med 2007;28:692-728. [PubMed: 17507086]

Spector R, Johanson CE. Vitamin transport and homeostasis in mammalian brain: focus on Vitamins B and E. J Neurochem 2007;103:425-438. [PubMed: 17645457]

Srivastava RA. Scavenger receptor class B type I expression in murine brain and regulation by estrogen and dietary cholesterol. J Neurol Sci 2003;210:11-18. [PubMed: 12736081]

Stocker A, Azzi A. Tocopherol-binding proteins: their function and physiological significance. Antioxid Redox Signal 2000;2:397-404. [PubMed: 11229353]

Tamaru Y, Hirano M, Kusaka H, Ito H, Imai T, Ueno S. alpha-Tocopherol transfer protein gene: exon skipping of all transcripts causes ataxia. Neurology 1997;49:584-588. [PubMed: 9270601]

Tanito M, Yoshida Y, Kaidzu S, Chen ZH, Cynshi O, Jishage K, Niki E, Ohira A. Acceleration of agerelated changes in the retina in alpha-tocopherol transfer protein null mice fed a Vitamin E-deficient diet. Invest Ophthalmol Vis Sci 2007;48:396-404. [PubMed: 17197560]

Terasawa Y, Ladha Z, Leonard SW, Morrow JD, Newland D, Sanan D, Packer L, Traber MG, Farese RV Jr. Increased atherosclerosis in hyperlipidemic mice deficient in alpha -tocopherol transfer protein and vitamin E. Proc Natl Acad Sci U S A 2000;97:13830-13834. [PubMed: 11095717]

Towfighi J. Effects of chronic vitamin E deficiency on the nervous system of the rat. Acta Neuropathol (Berl) 1981;54:261-267. [PubMed: 7270082]

Traber MG, Arai H. Molecular mechanisms of vitamin E transport. Annu Rev Nutr 1999;19:343-355. [PubMed: 10448528]

Traber MG, Ingold KU, Burton GW, Kayden HJ. Absorption and transport of deuterium-substituted 2R, 4'R,8'R-alpha-tocopherol in human lipoproteins. Lipids 1988;23:791-797. [PubMed: 3185112]

Ubbink JB, Hayward Vermaak WJ, Bissbort S. Rapid high-performance liquid chromatographic assay for total homocysteine levels in human serum. J Chromatogr 1991;565:441-446. [PubMed: 1874890] 
Vatassery GT, Angerhofer CK, Knox CA. Effect of age on vitamin E concentrations in various regions of the brain and a few selected peripheral tissues of the rat, and on the uptake of radioactive vitamin E by various regions of rat brain. J Neurochem 1984a;43:409-412. [PubMed: 6736958]

Vatassery GT, Angerhofer CK, Knox CA, Deshmukh DS. Concentrations of vitamin E in various neuroanatomical regions and subcellular fractions, and the uptake of vitamin $\mathrm{E}$ by specific areas, of rat brain. Biochim Biophys Acta 1984b;792:118-122. [PubMed: 6696923]

Vatassery GT, Angerhofer CK, Peterson FJ. Vitamin E concentrations in the brains and some selected peripheral tissues of selenium-deficient and vitamin E-deficient mice. J Neurochem 1984c;42:554558. [PubMed: 6693887]

Vatassery GT, Bauer T, Dysken M. High doses of vitamin E in the treatment of disorders of the central nervous system in the aged. Am J Clin Nutr 1999;70:793-801. [PubMed: 10539737]

Vatassery GT, Lam C, Smith WE, Quach HT. Apolipoprotein E exerts selective and differential control over vitamin E concentrations in different areas of mammalian brain. J Neurosci Res 2006;84:13351342. [PubMed: 16941498]

Vatassery GT, Quach HT, Smith WE, Krick TP, Ungar F. Analysis of hydroxy and keto cholesterols in oxidized brain synaptosomes. Lipids 1997;32:101-107. [PubMed: 9075199]

Vatassery GT, Smith WE, Quach HT. A liquid chromatographic method for the simultaneous determination of alpha-tocopherol and tocopherolquinone in human red blood cells and other biological samples where tocopherol is easily oxidized during sample treatment. Anal Biochem 1993;214:426-430. [PubMed: 8109730]

Yokota T, Igarashi K, Uchihara T, Jishage K, Tomita H, Inaba A, Li Y, Arita M, Suzuki H, Mizusawa $\mathrm{H}$, Arai H. Delayed-onset ataxia in mice lacking alpha -tocopherol transfer protein: model for neuronal degeneration caused by chronic oxidative stress. Proc Natl Acad Sci U S A 2001;98:1518515190. [PubMed: 11752462]

Yokota T, Shiojiri T, Gotoda T, Arai H. Retinitis pigmentosa and ataxia caused by a mutation in the gene for the alpha-tocopherol-transfer protein. N Engl J Med 1996;335:1770-1771. [PubMed: 8965888]

Yokota T, Wada Y, Furukawa T, Tsukagoshi H, Uchihara T, Watabiki S. Adult-onset spinocerebellar syndrome with idiopathic vitamin E deficiency. Ann Neurol 1987;22:84-87. [PubMed: 3477125]

\section{Acknowledgments}

Research was supported by NIH ES 011985-02, ES 011985, USDA (2003-00915), Clinical Nutrition Research Unit Pilot Research grant from the University of California and a grant from Center for Human Nutrition Research at University of California, Davis. Parts of the funds were from a Merit Review grant (to GTV) from the department of Veterans Affairs, Washington DC. 

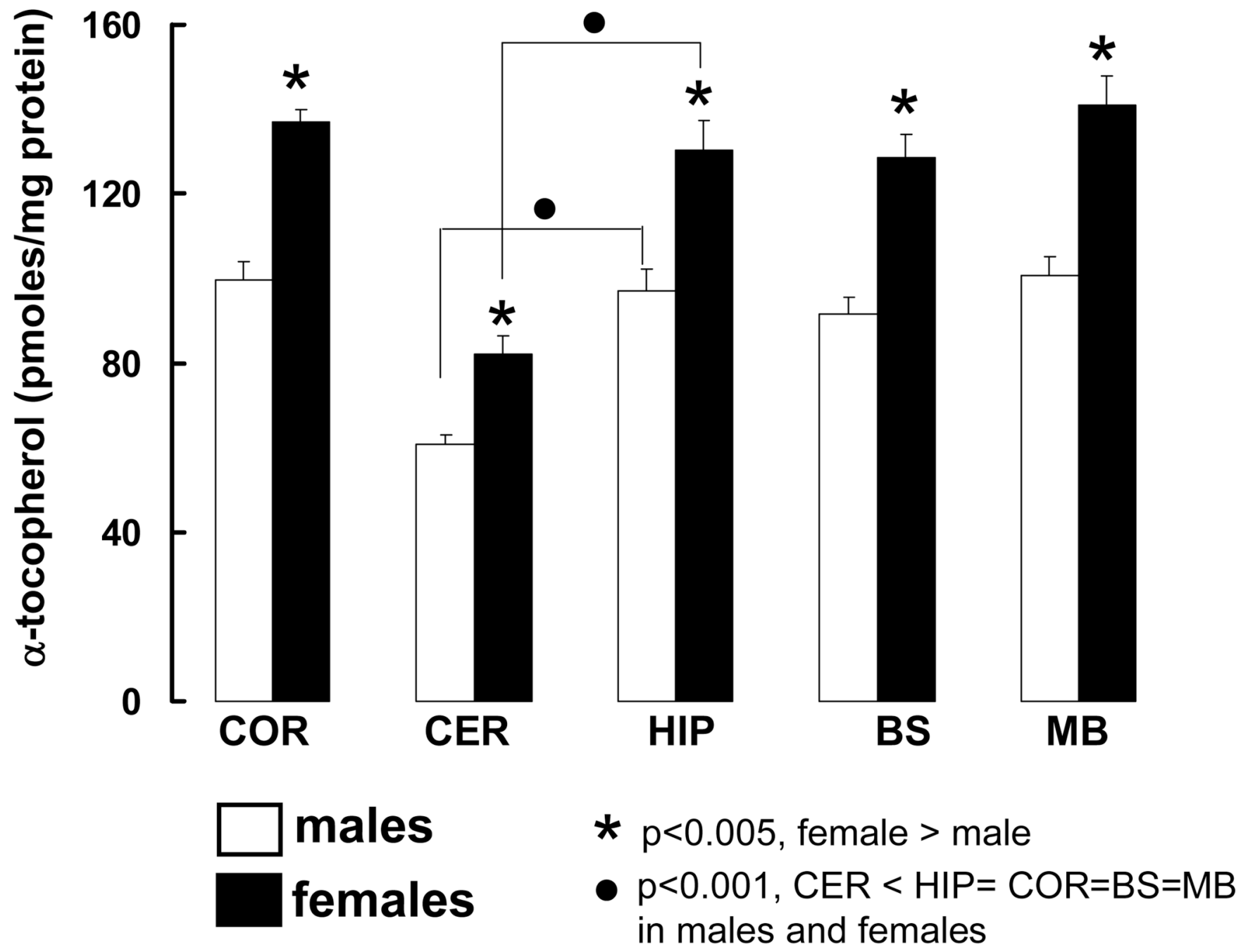

Figure 1. $\alpha$-T concentrations in five brain regions of 5 months-old WT male and female brains All brain regions from female mice $(n=5)$ contained significantly higher concentrations of $\alpha$-T than that from the brains of male mice $(n=3)$. $\alpha$-T concentration of the cerebellum was lower than that of the other brain regions. $\mathrm{COR}=$ cortex, $\mathrm{CER}=$ cerebellum, HIP $=$ hippocampus, $\mathrm{BS}=$ brainstem, $\mathrm{MB}=$ midbrain. 


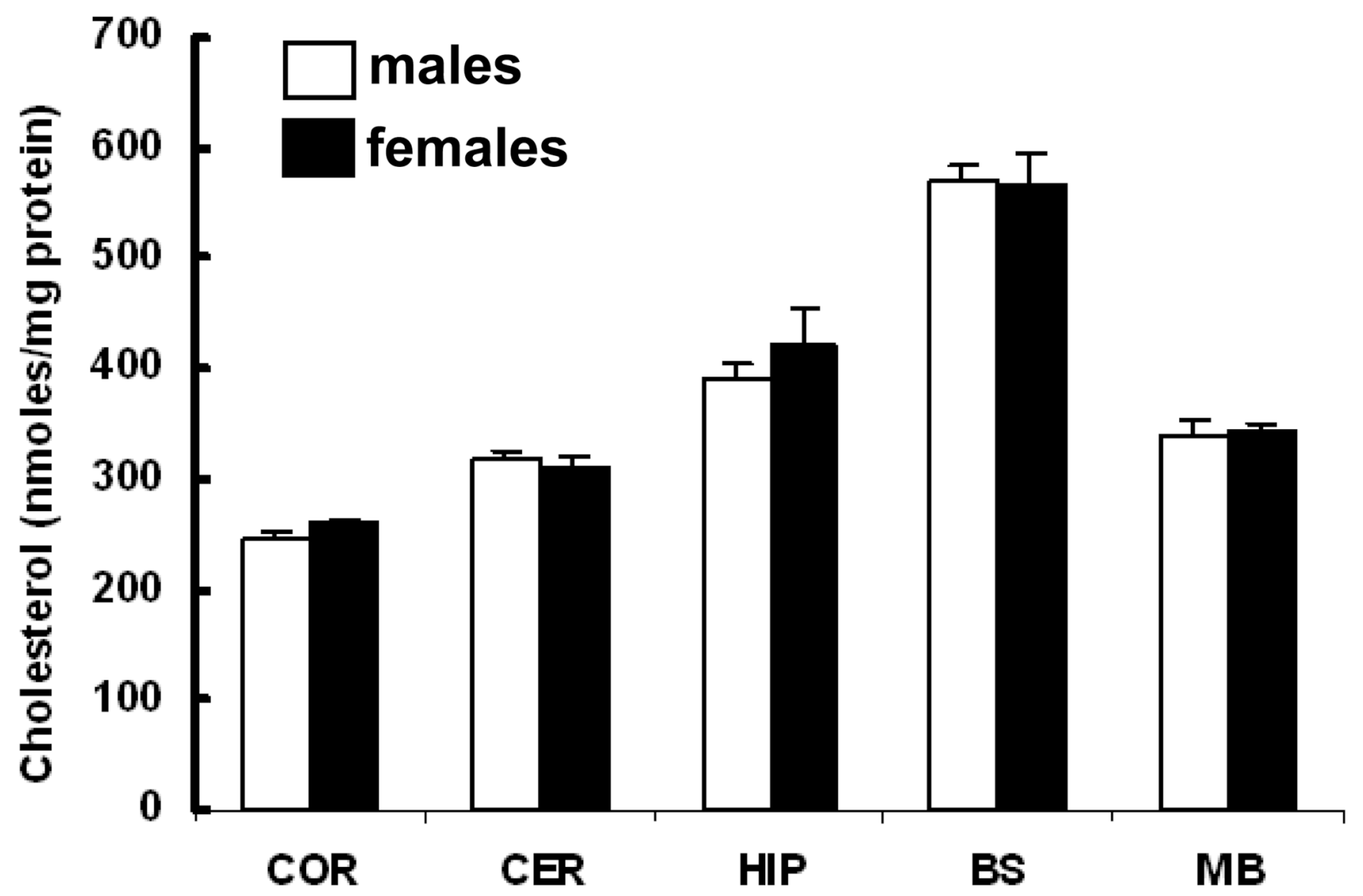

Figure 2. Cholesterol concentrations in male and female brain regions Cholesterol concentrations in five brain regions of 5 months-old WT male and female brains. Data show no significant effect of sex on the cholesterol concentrations in the five brain regions. $\mathrm{COR}=$ cortex, $\mathrm{CER}=$ cerebellum, $\mathrm{HIP}=$ hippocampus, $\mathrm{BS}=$ brainstem, $\mathrm{MB}=$ midbrain. The data show mean \pm SEM, $n=3$ for male mice and $n=5$ for female mice. 


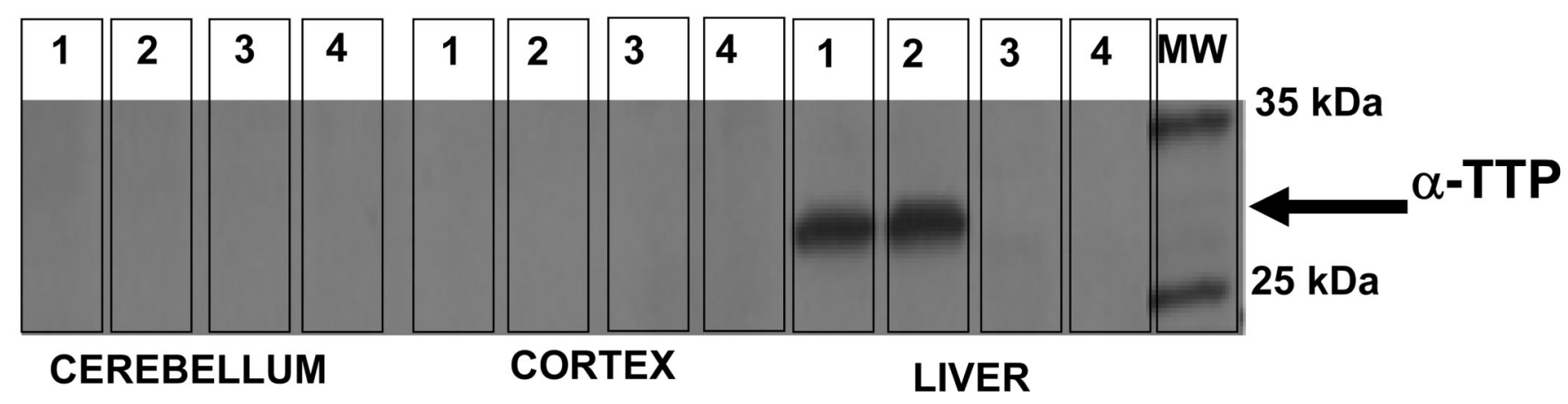

Figure 3. $\alpha$-TTP expression by immunoblot analysis

Immunoblot analysis of $\alpha$-TTP expression in cerebellum, cortex and, liver homogenates from $\mathrm{WT}(\mathrm{n}=2$, lanes 1 and 2$)$ and $\alpha$-TTP-KO $(\mathrm{n}=2$, lanes 3 and 4$)$ mice. Forty $\mu \mathrm{g}$ of protein from each tissue homogenate were resolved by PAGE and electro transferred to membranes as described in the Methods. The immunoblots were probed with rabbit anti- $\alpha$-TTP antiserum (a generous gift from Professor Maret G. Traber, Linus Pauling Institute, Oregon State University, Corvallis, OR, USA). A $\sim 32 \mathrm{kDa}$ protein was detected in livers from WT mice. The protein was absent in livers from $\alpha$-TTP-KO mice. The $\sim 32 \mathrm{kDa}$ anti- $\alpha$-TTP antiserum reactive protein was not detectable in cortex or in the cerebellum of either the WT or the $\alpha$-TTP-KO mice. MW= Molecular weight standards. 


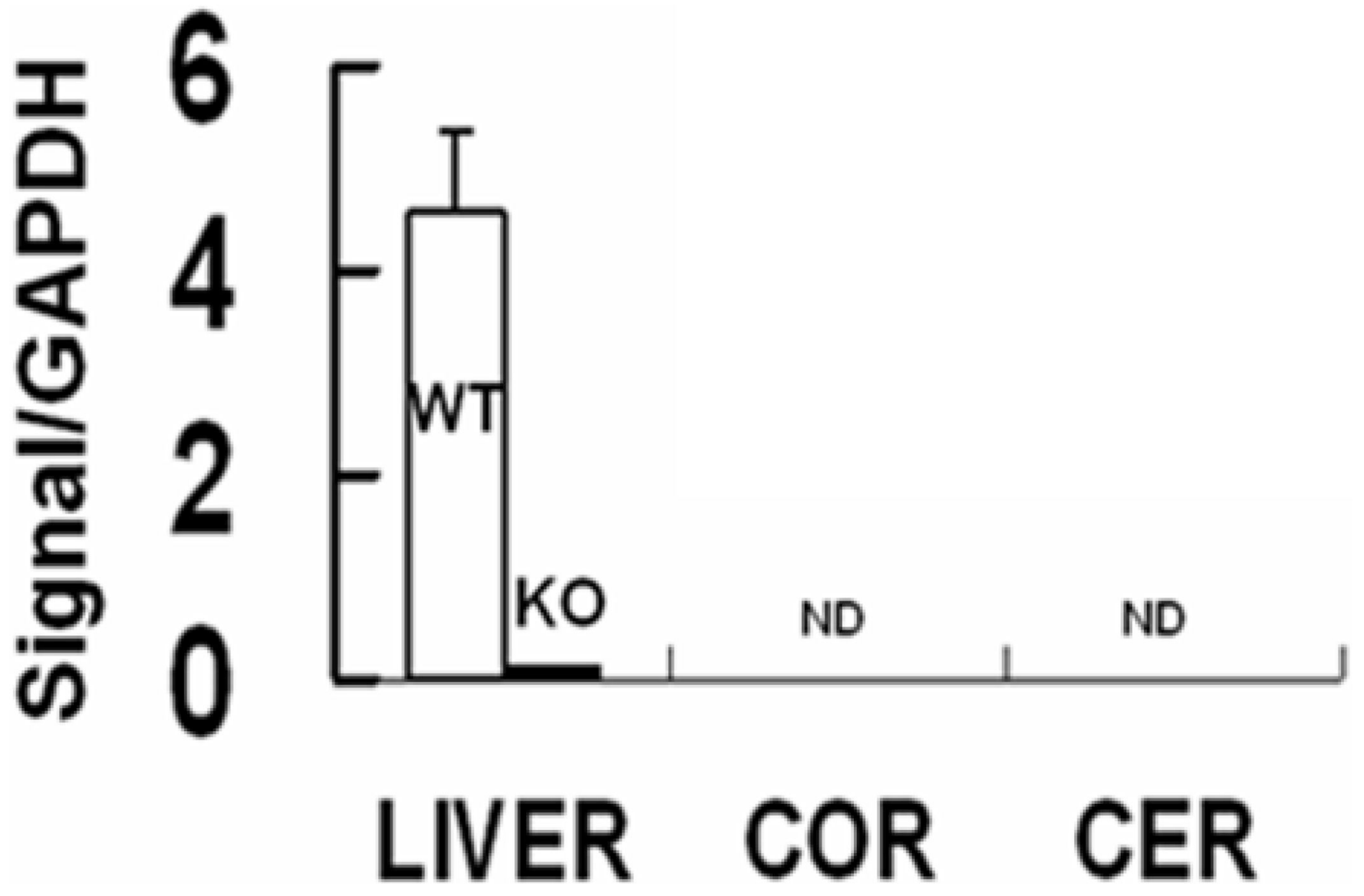

Figure 4. $\alpha$-TTP mRNA expression by qRT-PCR analysis

The expression of $\alpha$-TTP mRNA in cerebellum and cortex is undetectable by qRT-PCR assay. The data were normalized for the expression of GAPDH mRNA in the same samples. $\alpha$-TTP mRNA is abundantly expressed in livers from wild type (WT) mice and its expression is near the limit of detection in the livers from $\alpha$-TTP-KO mice. Its expression was not detectable (ND) in either the cerebellum or the cortex from the same mice. Data are mean \pm SEM, $n=5$. 


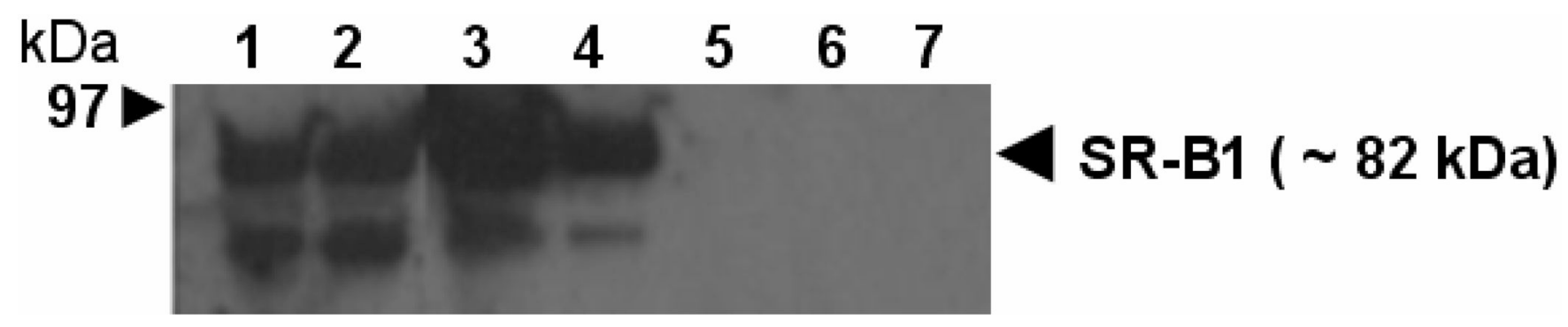

Figure 5. Scavenger receptor $\mathrm{B} 1$ expression is undetectable in brain regions

The data show abundant expression of the receptor $(\sim 82 \mathrm{kDa})$ in liver and adrenal glands but undetectable expression in the three brain regions. A $\sim 57 \mathrm{kDa}$ immunoreactive protein was also detected in livers and adrenal gland, and it probably is an unglycosylated SRB1. Aliquots of homogenates from WT liver (lane 1, $60 \mu \mathrm{g}$ protein), $\alpha$-TTP-KO liver (lane 2, $60 \mu \mathrm{g}$ protein), WT adrenal glands (lane 3, $60 \mu \mathrm{g}$ and lane 4, $20 \mu \mathrm{g}$ ), WT cerebellum, WT medulla and WT cortex (lanes 5, 6 and 7, respectively, $60 \mu \mathrm{g}$ protein each,) were processed for immunoblot detection of SR-B1 expression. The blots were over-exposed to enable visualization of the immunoreactive protein in the brain regions. 

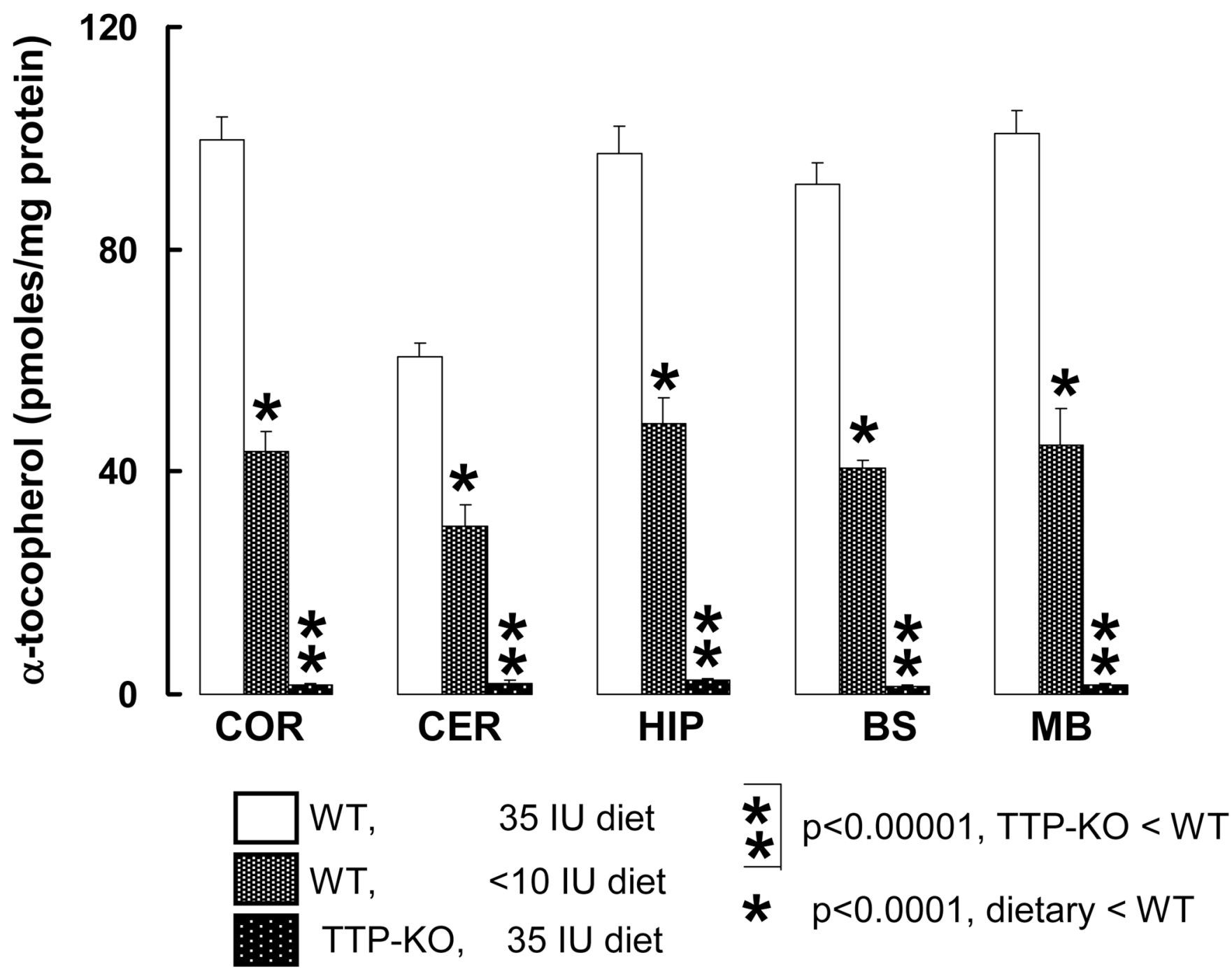

Figure 6. Brain regions of male a-TTP-KO mice are severely $\alpha$-T depleted IN AT

$\alpha$-T concentrations in the five regions of brains from five months-old male mice. The data show that $\alpha$-T concentrations in all brain regions were significantly $(\mathrm{p}<0.00001)$ lower than those in the brains of either the WT mice fed the same $\alpha-T$ diet (35 IU/kg diet) or in the brains of WT mice fed the $\alpha$-T deficient diet. The data show mean \pm SEM, $n=3$. COR $=$ cortex, CER = cerebellum, $\mathrm{HIP}=$ hippocampus, $\mathrm{BS}=$ brainstem, $\mathrm{MB}=$ midbrain . 
Females

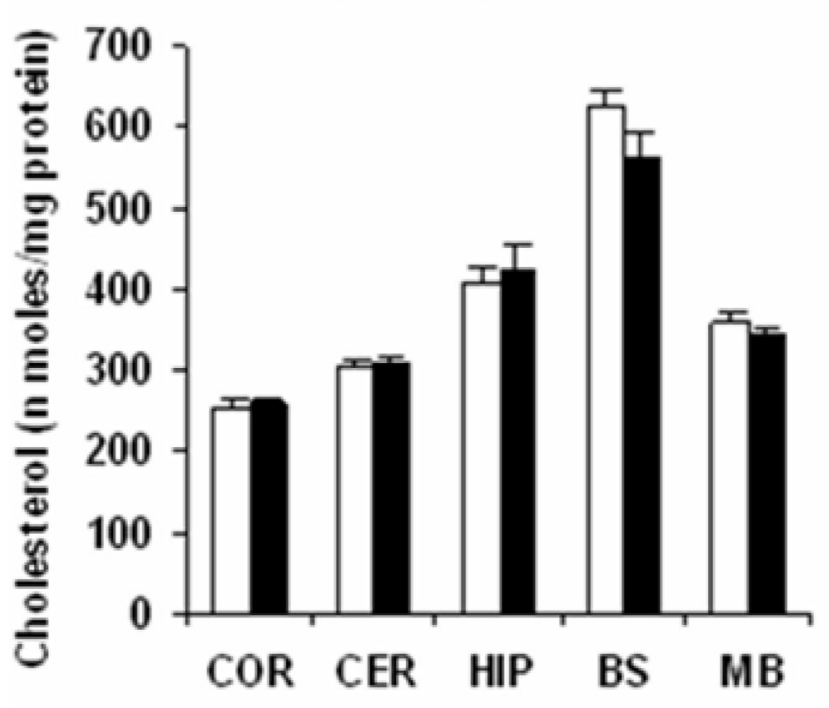

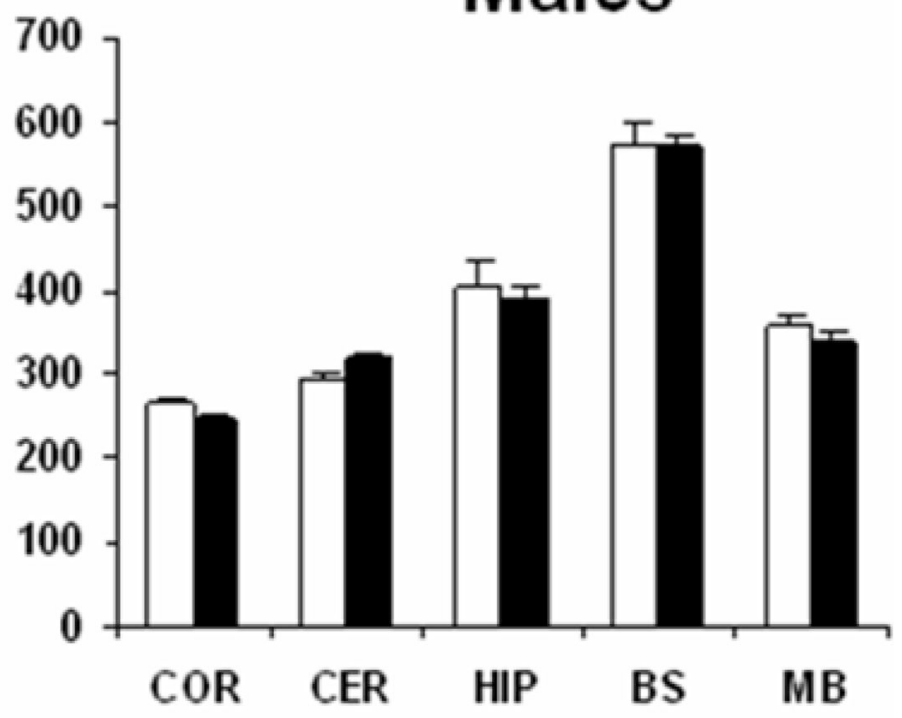

$\alpha-T T P-K O$

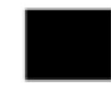

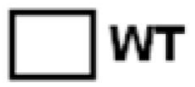

Figure 7. Cholesterol concentrations are unaffected by the absence of $\alpha$-TTP

Cholesterol concentrations in the five distinct anatomical regions of the female and male brains were unaffected by the absence of $\alpha$-TTP gene. COR = cortex, CER = cerebellum, HIP = hippocampus, $\mathrm{BS}=$ brainstem, $\mathrm{MB}=$ midbrain. The data show mean $\pm \mathrm{SEM}, \mathrm{n}=3$ for male mice and $\mathrm{n}=5$ for female mice. 


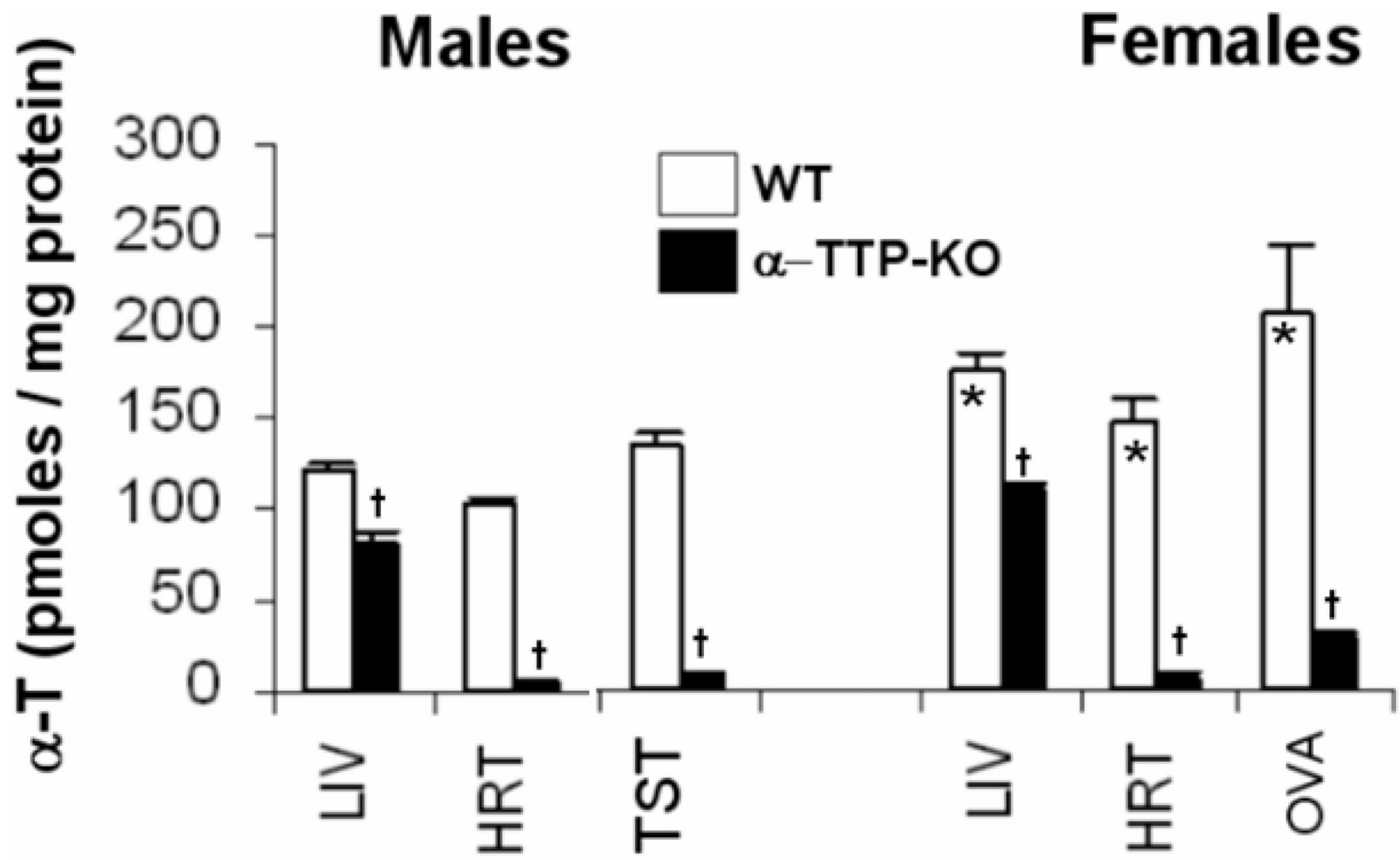

Figure 8. Differential effects of $\alpha$-TTP gene deletion on non-CNS tissues

$\alpha$-T concentrations in peripheral tissues of male and female mice of WT and $\alpha$-TTP-KO mice. $\alpha$-T concentrations in livers (LIV) and hearts (HRT) from WT female mice were significantly $(*, p<0.001)$ higher $(43 \%)$ than those in the male mice. $\alpha$-T in ovaries (OVA) was significantly higher than that in testes (TST). Absence of the $\alpha$-TTP gene resulted in a significant ( $\dagger, \mathrm{p}<$ $0.0001)$ and a large $(\sim 90 \%)$ decrease in the $\alpha$-T concentrations of heart, testes and ovaries. In contrast, the decrease in liver $\alpha$-T of $\alpha$-TTP-KO mice was smaller $(\sim 50 \%)$ than that of the other tissues. The data are mean $\pm \operatorname{SEM}(n=5-7)$ 


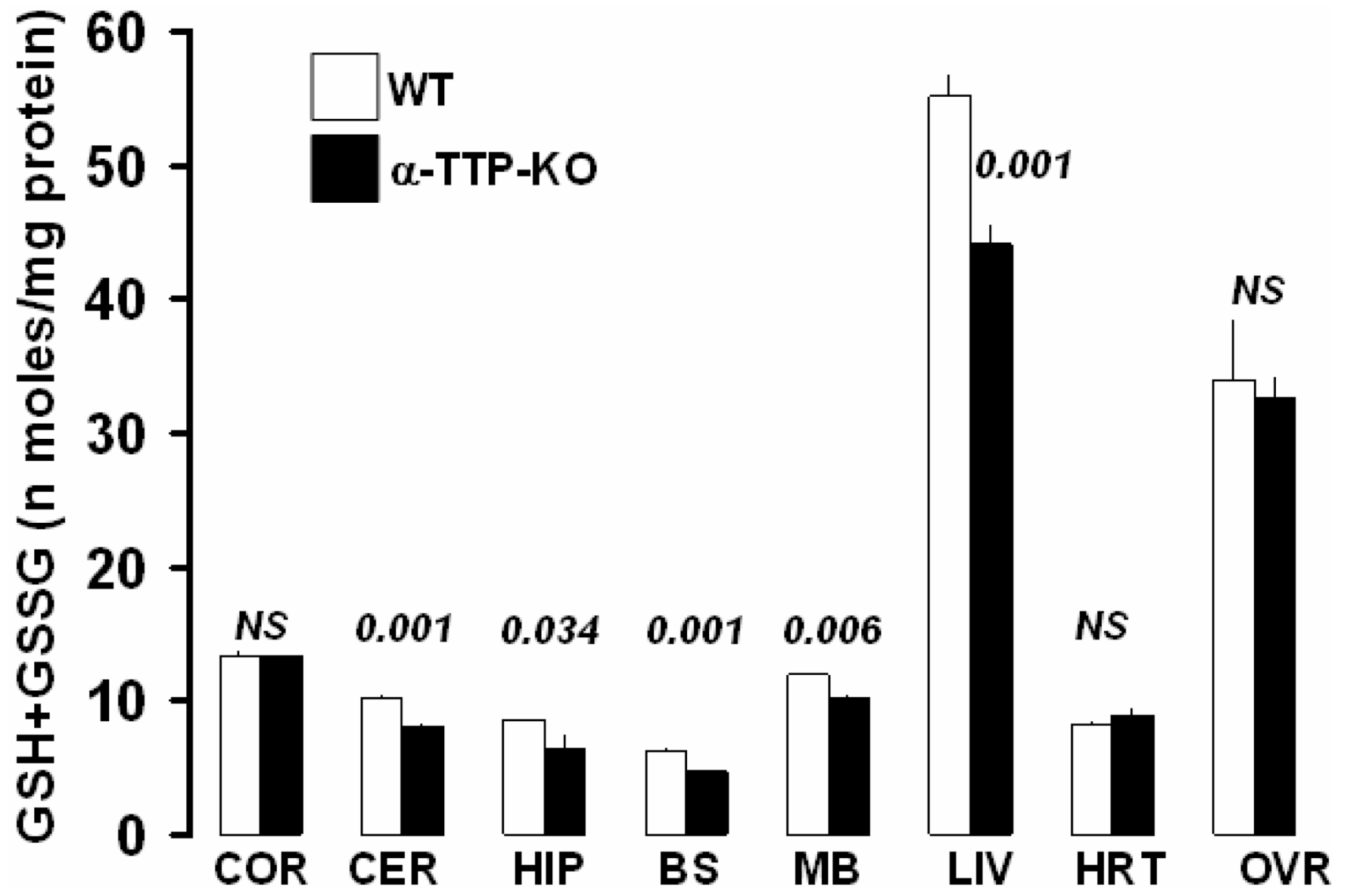

Figure 9. Glutathione concentrations in tissues of WT and $\alpha$-TTP-KO mice Absence of $\alpha$-TTP gene results in small but statistically significant decrease in total GSH of selected brain regions and in liver of female mice. The data are mean $\pm S E M, N=3-5$. Total GSH was significantly ( $\mathrm{p}<0.001-0.034$ ) lower $(\sim 7-18 \%)$ in cerebellum (CER), hippocampus (HIP), brainstem (BS), midbrain (MB) and liver (LIV) from $\alpha$-TTP-KO mice compared to that in the tissues from the WT mice. There was no significant difference (NS) between the WT and $\alpha$-TTP-KO mice for the total GSH in cortex (COR), heart (HRT), ovaries (OVA). 